\title{
ANALISIS KESULITAN KETERAMPILAN MENULIS \\ KARANGAN DESKRIPSI PESERTA DIDIK \\ DI SEKOLAH DASAR
}

\author{
Feby Inggriyani ${ }^{1}$, Nur Anisa Pebrianti ${ }^{2}$ \\ ${ }^{1}$ PGSD FKIP Universitas Pasundan, 2 SDN 129 Rancasawo Margasari \\ 1febyinggriyani@unpas.ac.id, 2nuranisa411@gmail.com
}

\begin{abstract}
This descriptive analysis study aims to determine the ability to write descriptive essays in fourth grade students at SDN Griya Bandung Indah. The data analysis method in this study used qualitative descriptive analysis. Data collection techniques used in this study were documentation and interviews. The average value of the ability to write descriptive essays is 54.6 with less qualifications. The percentage of suitability of the title with the theme of the essay is $66 \%$ or equal to 20 students including the very good/good category, the percentage of neatness of writing and accuracy of diction is $73.3 \%$ or equal to 22 people who are still not neat in their writing and choice of words/diction, the percentage of essay writing structure is $56.7 \%$ or equal to 17 people including very good/good category, percentage of suitability of ideas with essays is $63.3 \%$ or equal to 19 people who are still lacking in suitability of ideas with essays, and percentage of spelling usage In general, the Indonesian language is $87 \%$ or equal to 26 people, including the category of lacking in writing capital letters and using punctuation marks in accordance with general Indonesian spelling guidelines. The obstacles faced by students are that they find it difficult to express their ideas into words/sentences, this is due to the lack of interest of students in reading and the lack of students to get used to the practice seriously. Factors that influence learning difficulties in writing descriptive essays are intelligence, interest in learning, attitudes and behavior towards lessons, motivation, learning standards, factors from educators who use inappropriate media, methods, and learning tactics.
\end{abstract}

Keywords: difficulty analysis, descriptive essay, writing skills

\section{ABSTRAK}

Penelitian analisis deskriptif ini bertujuan untuk mengetahui kemampuan menulis karangan deskripsi peserta didik kelas IV SDN Griya Bandung Indah. Metode analisis data dalam penelitian ini menggunakan analisis dekriptif kualitatif. Teknik pengumpulan data yang digunakan dalam penelitian ini adalah dokumentasi dan wawancara. Rata-rata nilai kemampuan menulis karangan deskripsi yaitu 54,6 dengan kualifikasi kurang. Adapun persentase kesesuaian judul dengan tema karangan adalah $66 \%$ atau sama dengan 20 peserta didik termasuk kategori 
sangat baik/baik, persentase kerapihan tulisan dan ketepatan diksi adalah 73,3\% atau sama dengan 22 orang yang masih kurang rapi dalam penulisannya dan pilihankata/diksi, persentase struktur penulisan karangan adalah $56,7 \%$ atau sama dengan 17 orang termasuk kategori sangat baik/baik, persentase kesesuaian gagasan dengankarangan adalah $63,3 \%$ atau sama dengan 19 orang yang masih kurang dalam kesesuaian gagasan dengan karangan, dan persentase penggunaan ejaan umum bahasa indonesia adalah $87 \%$ atau sama dengan 26 orang termasuk kategori kurang dalam penulisan huruf kapital dan penggunaan tanda baca sesuai dengan pedomanumum ejaan bahasa indonesia. Hambatan yang dihadapi peserta didik yaitu merasa sulit dalam menuangkan ide yang dimilikinya menjadi bentuk kata/kalimat, hal ini disebabkan kurangnya minat peserta didik untuk membaca dan kurangnya peserta didik untuk membiasakan latihan dengan bersungguh-sungguh. Faktor yang memengaruhi kesulitan belajar dalam menulis karangan deskripsi yaitu kecerdasan, minat belajar, sikap dan perilaku terhadap pelajaran, motivasi, standar pelajaran faktor dari pendidik yang menggunakan media, metode, dan taktik pembelajaran yang belum tepat.

Kata kunci: analisis kesulitan, karangan deskripsi, keterampilan menulis

\section{A. Pendahuluan}

Pembelajaran menulis di Sekolah Dasar merupakan salah satu dari keterampilan berbahasa yang harus dikuasai dengan baik oleh peserta didik (Azizah, 2016:314). Selain itu, Dalman (2015:3) menjelaskanbahwa menulis adalah sebuah proses kreatif dalam menuangkan gagasan berbentuk bahasa tulis dengan tujuan untuk memberitahu, meyakinkan, dan menghibur orang lain. Adapun pendapat Nurhuda (2018: 2) yang menjelaskan bahwa aktivitas menulis bukan hanya sekedar menghadirkan pikiran atau perasaan, melainkan kegiatan menuangkan ide, pengetahuan, ilmu dan gagasan dalam bahasa tulis. Oleh karena itu, untuk menghasilkan tulisan yang baik tentunya harus dilakukan berkali-kali dengan cara latihan (Fatkasari dan Heru, 2017:728). Dengan demikian, dalam menulis diperlukan keterampilan dalam menuangkan gagasan atau ide secara jelas dan mampu menggunakan kalimat efektif dan mudah dipahami serta menggunakan kaidah penulisan yang baik sehingga bisa dipahami oleh pembaca.

Keterampilan di dalam menulis merupakan kemampuan paling sulit dibandingan dengan keterampilan lainnya. Hal ini disebabkan karena 
Didaktik : Jurnal IImiah PGSD STKIP Subang, ISSN Cetak : 2477-5673 ISSN Online : 2614-722X Volume 07 Nomor 01, Juni 2021

keterampilan menulis menuntut untuk mempunyai pengetahuan menguasai kosakata, pengetahuan, dan pengalaman agar mampu menyampaikan gagasan penulis kepada pembaca secara sistematis. Oleh sebab itu, keterampilan menulis sangat perlu untuk ditanamkan sejak dini kepada peserta didik disekolah dasar untuk melatih peserta didik berpikir kritis, logis, serta dapat mengungkapkan ide atau gagasan dalam bentuk tulisan.

Pembelajaran kegiatan menulis di sekolah dasar mencakup dua bagian, yaitu pembelajaran menulis permulaan dan menulis lanjut. Hal ini sejalan dengan pendapat Santoso (2013:8-35) yaitu pembelajaran dalam kegiatan menulis di sekolah dasar terdiri dari menulis permulaan dan menulis lanjut. Menulis permulaan di kelas rendah yaitu kelas satu sampai dengan tiga. Sedangkan menulis lanjut dilaksanakan di kelas tinggi yaitu kelas empat sampai enam dan menulis lanjutan merupakan pengembangan dari menulis permulaan peserta didik.

Kegiatan menulis yang terdapat pada kelas tinggi yaitu 1) menulis lanjut, 2) menulis dengan bantuan gambar, 3) menulis paragraf, 4) menulis karangan sederhana yang meliputi narasi, deskripsi, eksposisi, argumentasi, dan peruasi, 4) menulis surat, 5) menulis, 6) menulis naskah pidato, 7) menulis ceramah, 8) menulis berita, dan 9) menulis formulir (Zulela, 2013, hlm. 9) Dengan demikian, dapat disimpulkan bahwa salah satu bentuk kegiatan menulis di kelas tinggi yaitu menulis karangan sederhana yang harus dibuat oleh peserta didik.

Karangan adalah suatu karya tulis hasil yang mengungkapkan gagasan atau ide yang dituangkan dalam bentuk tulisan dan disampaikan kepada pembaca untuk dipahami dan merasakan apa yang dialami oleh penulis (Sayuti, dkk, 2016:119). Salah satu bentuk karangan yang diajarkan pada peserta didik sekolah dasar adalah menulis karangan deskripsi. Seperti yang tercantum dalam kurikulum 2013 karangan deskripsi sudah diperkenalkan dan diajarkan kepada peserta didik sekolah dasar kelas tinggi yaitu kelas IV.

Dalman (2015:94) menjelaskan karangan deskripsi merupakan karangan yang melukiskan atau menggambarkan suatu objek atau 
peristiwa tertentu dengan kata- kata secara jelas dan terperinci sehingga pembaca seolah-olah turut merasakan ataumengalami langsung apa yang dideskripsikan penulis. Adapun pendapat Tarigan (2013:52) menyatakan bahwa karangan deskripsi ialah tulisan yang berusaha melukiskan dan mengemukakan objek yang sedang dibicarakan (seperti orang, tempat, suasana atau yang lainnya). Dengan demikian dapat disimpulkan bahwa karangan deskripsi merupakan jenis karangan yang menjelaskan, melukiskan tentang suatu hal secara rinci, sehingga membuat pembaca seolah-olah menghayati, melihat, mendengar, dan merasakan langsung objek yang dipaparkan. Selain itu, dalam membuat karangan deskripsi penulis pun perlu memperhatikan ciri-cirinya sehingga tulisannya bisa dipahami.

Keraf dalam (Dalman, 2018:95) menjelaskan bahwa karangan deskripsi mempunyai ciri-ciri sebagai berikut, (1) berisi tentang perincian sehingga objeknya terbayang di depan mata, (2) dapat menimbulkan kesan dan daya khayal pada pembaca, (3) berisi penjelasan yang menarik minat orang lain, (4) menyampaikan sifat dan perincian wujud yang dapat ditemukan dalam objek itu, dan (5) menggunakan bahasa yang hidup, kuat, dan semangat. Oleh karena itu, untuk mudah dipahami dalam menulis karangan deskripsi perlu memiliki kriteria tertentu, antara lain kesesuaian judul, kerapihan tulisan dan ketepatan diksi, struktur penulisan karangan, dan kesesuaian gagasan karangan, dan eyd (Nurgiyantoro, 2010:440).

Berdasarkan teori tersebut, maka hal yang harus diperhatikan oleh peserta didik dalam menulis karangan deskripsi yaitu kesesuaian judul dengan tema yang menarik, kerapihan tulisan dan diksi yang tepat, struktur penulisan karangan, kesesuaian gagasan karangan yang dapat menggambarkan karangan dengan tema, karangan dapat tersusun dengan sistematis, adanya kesesuaian dengan kelengkapan tanda baca, penggunaan ejaan sesuai dengan eyd, dan penggunaan huruf kapital sehingga tidak ada lagi masalah didalam menulisnya.

Munculnya permasalahan yang dihadapi peserta didik dalam menulis karangan deskripsi yaitu disebabkan adanya faktor yang mengambat 
Didaktik : Jurnal IImiah PGSD STKIP Subang, ISSN Cetak : 2477-5673 ISSN Online : 2614-722X Volume 07 Nomor 01, Juni 2021

dalam kemampuan menulis karangan deskripsi. Nurhuda (2018:5) mengemukakan beberapa permasalahan dan kesulitan dalam menulis karangan deskripsi yaitu menemukan ide bahan tulisan, dan menentukan kosakata yang akan ditulis dalam menyusun kalimat. Sedangkan menurut Fatkasari (2017:727) faktor utama yang dihadapi peserta didik terhadap pembelajaran menulis deskripsi yaitu masih dilakukannya pembelajaran yang masih bersifat konvensional. Hal itu dibuktikan dengan nilai peserta didik belum bisa mencapai KKM, dikarenakan peserta didik belum terbiasa menulis karangan deskripsi, dan guru belum menggunakan model pembelajaran yang menarik, serta kurangnya memberikan strategi menulis yang tepat sehingga peserta didik kurang aktif dalam berinteraksi dan mengembangkan gagasan atau idenya. Dengan demikian, dapat disimpulkan bahwa faktor rendahnya kemampuan menulis pada peserta didik yaitu rendahnya peran guru dalam pembinaaan menulis dan guru tidak menggunakan strategi menulis yang tepat sehingga peserta didik kurang aktif dalam berinteraksi untuk mengembangkan idenya. Hal itu merupakan tantangan guru dalam membina peserta didik supaya keterampilan menulisnya lebih baik.

Permasalahan di atas sesaui dengan hasil observasi dan wawancara dengan guru kelas IV SD Negeri Griya Bandung Indah, peneliti menemukan masih ada beberapa peserta didik yang kemampuan menulisnya masih rendah dibawah KKM yaitu 65. Peserta didik belum sepenuhnya mampu dalam menulis. Hal ini disebabkan karena peserta didik tidak mampu menuangkan idenya dalam menulis, keterbatasan dalam menggunakan ejaan atau tanda baca, dan ketidakmampuan guru dalam menentukan metode dan model pembelajaran yang sesuai untuk keterampilan menulis. Permasalahan tersebut dapat dilihat dari rendahnya kemampuan peserta didik dalam menulis yang masih membutuhkan waktu yang cukup lama, dalam kegiatan pembelajaran pun guru masih menggunakan pembelajaran konvensional dan belum menggunakan model pembelajaran bervariatif. Oleh karena itu, diperlukan perhatian yang serius mengenai menulis peserta didik dan perlu diberikan latihan yang terus 
menerus supaya peserta didik terampil dalam menulis dan masalah kesulitan belajar khususnya menulis.

Berdasarkan permasalahan tersebut, peneliti tertartik untuk melakukan penelitian dengan judul "Analisis Keterampilan Menulis Karangan Deskripsi Peserta Didik Kelas IV SD Negeri Griya Bandung Indah".

\section{B. Metode Penelitian}

Jenis penelitian yang dilakukan dengan menggunakan deskriptif kualitatif melalui metode analisis. Bogdan dan Taylor (dalam Moleong, 2010:4) mengemukakan bahwa penelitian kualitatif adalah prosedur penelitian yang menghasilkan data deskriptif berupa kata-kata tertulis atau lisan dari orang-orang dan prilaku yang dapat diamati peneliti.

Subjek pada penelitian ini adalah wali kelas IV SD Negeri Griya Bandung Indah, dan peserta didik kelas IV SD Negeri Griya Bandung indah dengan berjumlah 30 siswa, terdiri dari 11 siswa perempuan dan 19 siswa laki-laki. Sedangkan objek di dalam penelitian kualitatif ini terdiri dari dokumentasi hasil kerja peserta didik yaitu menulis karangan deskripsi untuk menganalisis kesulitan dalam menulis karangan deskripsi.

Dalam penelitian ini penulis memperoleh data dari peserta didik dalam bentuk tes menulis karangan deskripsi. Adapun langkah-langkah yang akan ditempuh adalah sebagai berikut :

1) Melakukan wawancara terhadap guru untuk mengetahui informasiinformasi mengenai menulis karangan deskrispsi pada peserta didik.

2) Memperoleh dokumentasi sebagai bukti hasil tes menulis karangan deskpsi yang telah dikerjakan oleh peserta didik secara individu.

Selanjutnya melakukan analisis data dengan pengumpulan data, dan menelaah seluruh data yang dimulai dengan berbagai sumber yaitu dari hasil wawancara dan hasil dokumentasi untuk mempermudah pemahaman terhadap data yang telah terkumpul sehingga data yang direduksi memberikan gambaran lebih rinci dan pada tahap akhir dalam proses penelitian mampu memberikan makna terhadap data yang telah dianalisis.

\section{C.Hasil Penelitian dan Pembahasan}

Berdasarkan hasil analisis, diperoleh data keterampilan menulis 
Didaktik : Jurnal IImiah PGSD STKIP Subang, ISSN Cetak : 2477-5673 ISSN Online : 2614-722X Volume 07 Nomor 01, Juni 2021

karangan deskripsi peserta didik, hambatan yang dihadapi guru dan peserta didik dalam keteterampilan menulis karangan deskripsi dan faktor yang memengaruhi keterampilan menulis karangan deskripsi. Untuk data keterampilan menulis diperoleh dari hasil tes yang diberikan oleh guru kepada peserta didik, dan tes ini mengacu pada setiap indikator menulis karangan deskripsi .

Kemampuan menulis karangan deskripsi yang diperoleh peserta didik kelas IV SDN Griya Bandung Indah melalui analisis tes dengan nilai tertinggi 95 dan nilai terendah 25 . Rata-rata nilai kemampuan menulis karangan deskripsi peserta didik secara klasikal memperoleh 54,6 berada pada kualifikasi kurang berdasarkan Penilaian Acuan Patokan (PAP) skala empat tentang keterampilan menulis karangan deskripsi. Pertihungan yang dilakukan sebagai berikut.

$$
\begin{aligned}
M & =\frac{\sum x}{n} \\
& =\frac{1 \cdot 640}{30} \\
& =54,6
\end{aligned}
$$

Untuk mengetahui hasil nilai kemampuan menulis karangan deskripsi dapat dilihat dari 5 aspek keterampilan menulis karangan deskripsi yang telah ditentukan yaitu kesesuaian judul, kerapihan tulisan dan ketepatan diksi, struktur penulisan karangan, kesesuaian gagasan dengan karangan, dan kesesuaian dengan pedoman umum ejaan bahasa Indonesia.

Berdasarkan hasil rekapitulasi keterampilan menulis karangan deskripsi, diperoleh bahwa nilai yang diperoleh peserta didik cenderung sama. Nilai tertinggi yang berkisar 85 sampai 96 diperoleh sekitar 1 orang peserta didik sedangkan nilai terendah dengan interval 25 sampai 36 diperoleh sekitar 7 peserta didik. Selain itu, nilai rata-rata yang diperoleh pada kelas ketiga sekitar $36,7 \%$ dan merupakan nilai peserta didik yang berada di bawah nilai ratarata, serta sekitar $63,3 \%$ nilai peserta didik berada pada nilai rat-rata.

Adapun nilai yang diperoleh peserta didik berdasarkan aspek keterampilan menulis karangan deskripsi peserta didik yaitu sebagai berikut:

\section{Kesesuaian Judul}

Terdapat 11 orang peserta didik dapat dikategorikan sangat baik 
Didaktik : Jurnal IImiah PGSD STKIP Subang, ISSN Cetak : 2477-5673 ISSN Online : 2614-722X Volume 07 Nomor 01, Juni 2021

dalam menulis karangan deskripsi pada aspek kesesuaian menentukan judul, 9 orang dikategorikan baik, 6 orang dikategorikan cukup dan 4 peserta didik yang dikategorikan kurang dalam aspek kesesuaian dalam menentukan judul.

\section{Kerapihan tulisan dan ketepatan} diksi

Terdapat 1 orang peserta didik dikategorikan sangat baik dalam menulis karangan deskripsi pada aspek kerapihan tulisan dan ketepaten diksi, 7 orang dikategorikan baik, 7 orang dikategorikan cukup dan 15 orang peserta didik yang dikategorikan kurang pada aspek kerapihan tulisan dan ketepatan diksi didalam menulis karangan deskripsi.

\section{Struktur penulisan karangan}

Terdapat 5 orang peserta didik dikategorikan sangat baik dalam menulis karangan deskripsi pada aspek struktur penulisan karangan, dan terdapat 12 orang dikategorikan baik, 8 orang dikategorikan cukup dan hanya 5 orang peserta didik yang dikategorikan kurang pada aspek struktur penulisan karangan peserta didik.

\section{Kesesuaian gagasan dengan karangan}

Terdapat 2 orang peserta didik dikategorikan sangat baik dalam menulis karangan deskripsi pada aspek kesesuaian gagasan dengan karangan, 9 orang dikategorikan baik, 11 orang dikategorikan cukup dan hanya 8 orang peserta didik yang dikategorikan kurang dalam aspek kesesuaian gagasan dengan karangan.

\section{Pedoman umum ejaan bahasa indonesia}

Terdapat 1 orang peserta didik dikategorikan sangat baik dalam menulis karangan deskripsi pada aspek pedoman umum ejaan bahasa indonesia, 3 orang dikategorikan baik, 7 orang dikategorikan cukup dan 19 orang peserta didik yang dikategorikan kurang dalam aspek pedoman umum ejaan bahasa indonesia.

Berikut ini disajikan tabel data rekapitulasi hasil analisis menulis per aspek keterampilan menulis karangan deskripsi.

Tabel 1.1 Hasil Rekapitulasi 


\section{Keterampilan Menulis Karangan Deskripsi}

\begin{tabular}{|c|c|c|c|c|}
\hline \multirow[b]{2}{*}{ No } & \multirow[b]{2}{*}{ Aspek } & \multicolumn{2}{|c|}{ Persentase } & \multirow[b]{2}{*}{ Katergori } \\
\hline & & $\begin{array}{c}\text { Sangat } \\
\text { Baik/Baik }\end{array}$ & Kurang & \\
\hline 1 & Kesesuaian Judul & $66 \%$ & $34 \%$ & Baik \\
\hline 2 & $\begin{array}{l}\text { Kerapihan tulisan dan ketepatan } \\
\text { diksi }\end{array}$ & $26,7 \%$ & $73,3 \%$ & Kurang \\
\hline 3 & Struktur penulisan karangan & $56,7 \%$ & $43,3 \%$ & Cukup \\
\hline 4 & $\begin{array}{l}\text { Kesesuaian gagasan dengan } \\
\text { karangan }\end{array}$ & $36,7 \%$ & $63,3 \%$ & Kurang \\
\hline 5 & $\begin{array}{l}\text { Pedoman umum ejaan bahasa } \\
\text { indonesia }\end{array}$ & $13 \%$ & $87 \%$ & Kurang \\
\hline
\end{tabular}

Berdasarkan tabel di atas dapat diketahui rata-rata pesentase masingmasing aspek yaitu kesesuaian judul dengan tema karangan adalah $66 \%$ atau sama dengan 20 peserta didik termasuk katerogi sangat baik/ baik , sedangkan sisanya yaitu $34 \%$ atau sama dengan 10 peserta didik masih belum mampu menetukan judul sesuai dengan tema karangan.

Kerapihan tulisan dan ketepatan diksi adalah adalah $26,7 \%$ atau sama dengan 8 orang termasuk kategori sangat baik/baik, sedangkan sisanya $73,3 \%$ atau sama dengan 22 orang yang masih kurang rapi dalam penulisannya dan pilihan kata/diksi.

Struktur penulisan karangan adalah $56,7 \%$ atau sama dengan 17 orang termasuk kategori sangat baik/baik, sedangkan sisanya $43,3 \%$ atau sama dengan 13 orang yang masih kurang dalam struktur penulisan karangan.

Kesesuaian gagasan dengan karangan adalah $36,7 \%$ atau sama dengan 11 orang termasuk kategori sangat baik/baik, sedangkan sisanya $63,3 \%$ atau sama dengan 19 orang yang masih kurang dalam kesesuaian gagasan dengan karangan.

Penggunaan ejaan umum bahasa indonesia adalah $13 \%$ atau sama dengan 4 orang yang termasuk kategori sangat baik/baik, sedangkan sisanya adalah $87 \%$ atau sama dengan 26 orang termasuk kategori kurang dalam penulisan huruf kapital 
dan penggunaan tanda baca sesuai dengan pedoman umum ejaan bahasa indonesia.

Berdasarkan analisis diatas, kemampuan menulis karangan deskripsi peserta didik di kelas IV SDN Griya Bandung Indah termasuk dalam kategori kurang. Beberapa kriteria yang belum mampu dicapai peserta didik, terutama pada pengolahan kata dan penggunaan tanda baca. Peserta didik kurang mampu menggunakan kata baku atau belum sesuai PUEBI dalam tulisannya serta kurang memperhatikan tanda baca. Oleh karena itu, kemampuan menulis karangan deskripsi masih perlu ditingkatkan.

Untuk mengetahui hambatan yang dihadapi peserta didik dalam menulis karangan deskripsi, peneliti menganalisa hasil dokumentasi dan wawancara yang dilakukan dengan peserta didik dan guru kelas IV SDN Griya Bandung Indah. Dari hasil dokumentasi secara keseluruhan peserta didik memiliki kendala dalam menulis karangan deskripsi. Peserta didik masih kurang siap menulis sebuah karangan. Untuk menentukan topik yang akan dideskripsikan pun peserta didik masih bingung dan perlu diberikan contoh terlebih dahulu.
Selain itu, peserta didik tidak menulis dalam bentuk kasar ide yang dimiliknya terlebih dahulu.Oleh karena itu, peserta didik terkadang lupa dengan ide yang dimiliki untuk dituangkan bentuk kata/kalimat.

Ide yang disusun peserta didik pun masih tergolong kurang teratur karena ide yang disusun menjadi kata/kalimat masih kurang bekaitan antara satu kata/kalimat dengan kata/kalimat selanjutnya. Dengan kata lain, peserta didik miskin kata-kata. Karangan yang disusun peserta didik rata-rata hanya sekitar 4-6 kalimat. Pemikiran peserta didik kurang berkembang. Oleh karena itu, peserta didik tidak mampu mengembangkan kalimat yang disusun, masih kurang memerhatikan bentuk tulisannya, misalnya jarak antar kata yang masih berantakan yang menyebabkan pembaca kurang memahami maksud kalimatnya. Penggunaan tanda baca tidak diperhatikan dan tidak digunakan sehingga tulisannya tidak jelas dibaca. Selain itu, hasil karangan yang dituliskan peserta didik tidak pernah dipublikasikan.

Berdasarkan hasil wawancara dengan guru, secara umum pada setiap proses pembelajran terdapat beberapa kendala yang dialami guru. 
Khususnya dalam mengajar menulis karangan deskripsi, terdapat beberapa kendala yang dialami guru. Namun, meskipun menemukan kendala dalam mengajar, guru berusaha mencari dan memikirkan cara untuk mengatasi kendala yang dialaminya. Hal ini menjadi tantangan bagi guru untuk terus berlatih dan memperbaiki kualitas mengajar agar mampu mengatasi kendala tersebut.

Dalam menulis karangan deskripsi, guru mengakui bahwa terdapat kendala yang biasanya dihadapi yaitu peserta didik. Peserta didik masih merasa kesulitan menuangkan ide yang dimilikinya ke dalam bentuk kata/menyusun menjadi kalimat. Guru merasa kesulitan membuka pemikiran peserta didik untuk menuangkan idenya sehingga menjadi kalimat. Hal ini menyebabkan minimnya kata-kata yang disusun menjadi sebuah karangan. Selain itu, guru belum menggunakan model pembelajaran yang tepat dan efektif dalam mengembangkan kemampuan menulis karangan narasi peserta didik kelas IV.

1. Kemampuan Menulis Karangan Deskripsi Peserta Didik Kelas IV SDN Griya Bandung Indah
Berdasarkan hasil penelitian menunjukan bahwa secara umum kemampuan menulis karangan deskripsi masih tergolong kategori kurang. Dengan rata-rata nilai kemampuan menulis karangan deskripsi peserta didik secara klasikal memperoleh 54,6 berada pada kualifikasi kurang, dan diperoleh nilai tertinggi 95 dan nilai terendah 25. Hal ini menunjukan bahwa peserta didik kurang mampu untuk menciptakan ide dan gagasan yang akan dituangkan dalam bentuk tulisan yang bersifat deskripsi. Oleh karena itu, menulis karangan deskripsi harus sesuai dengan kriteria yang ditentukan agar dapat menghasilkan karangan deskripsi yang baik.

Hal ini sejalan dengan pendapat Nurgiyantoro (2010:441) yaitu judul, kerapihan tulisan dan ketepatan diksi, stuktur penulisan karangan, kesesuaian gagasan karangan, dan penulisan sesuai dengan Pedoman Umum Ejaan Bahasa Indonesia. Kelima kriteria tersebut juga dijadikan pedoman penilaian yang digunakan untuk menilai hasil karangan deskripsi yang dikerjakan peserta didik.

Isi karangan yang ditulis peserta didik sudah sesuai dengan judul yang dipilih peserta didik, akan tetapi masih 
ada beberapa peserta didik yang hanya menulis tema saja tidak mencantumkan judul. Namun, secara keseluruhan menunjukan bahwa peserta didik sudah mampu mendeskripsikan objek yang diamati dengan tepat. Pemilihan judul merupakan langkah pertama yang harus dilakukan sebelum menulis karangan deskripsi. Hal ini sejalan dengan pendapat Dalman (2014:103) bahwa judul karangan pada dasarnya perincian atau jabaran dari topik karangan.

Berdasarkan hasil yang diperoleh dari tulisan peserta didik, gagasan yang dikemukakan sudah sesuai tema, logis dan teratur, meskipun masih menggunakan kalimat yang sederhana dan objek tersebut secara singkat. Menulis karangan deskripsi membutuhkan pengetahuan luas untuk dapat memaparkan objek yang diamati secara menyeluruh. Hal ini sejalan dengan pendapat Dalman (2014:103) yang menyatakan bahwa karangan deskripsi adalah pemaparan kata-kata yang menggambarkan tentang suatu benda atau tempat.

Kerapihan hasil karangan yang ditulis peserta didik pun masih tampak kurang rapi dan perlu ditingkatkan lagi. Hal ini disebabkan oleh banyaknya coretan dalam tulisan peserta didik, masih banyak yang tidak terbaca dan kurangnya jarak penulisan yang mesti diatur oleh peserta didik. Oleh karena itu, sangat perlu latihan menulis yang harus dilakukan peserta didik agar menghasilkan tulisan yang bagus.

Pilihan kata atau diksi yang digunakan peserta didik sudah cukup, namun terdapat beberapa kata yang digunakan masih kurang tepat dan tidak sesuai dengan konteks baku. Penggunaan kata baku masih kurang dipahami peserta didik, sebagain besar peserta didik masih menggunakan kata tidak baku dalam karangan yang ditulisnya. Adapun struktur penulisan karangan yang disusun peserta didik sudah cukup, sudah tampak kesatuan, kesejajaran bentuk, dan kehematan dalam menggunakan kata sudah cukup terlihat.

Kesesuaian gagasan dalam karangan yang ditulis peserta didik cukup dan keterpaduan antar kalimat masih sangat kurang. Sebagian besar peserta didik menulis karangan deskripsi hanya terdiri dari satu paragraf yang berisikan uraian yang singkat, jadi tidak dapat diketahui 
adanya hubungan paragraf satu dengan paragraf lainnya yang ditulis peserta didik. Padahal, menulis karangan deskripsi hendaknya terdiri dari beberapa paragraf yang di susun dengan kalimat yang jelas secara terperinci agar objek yang dideskripsikan dapat dipahami oleh pembaca yang seakan-akan pembaca merasakan objek yang dideskripsikan tersebut. Hal ini sejalan dengan pendapat Keraf (2010:149) yang menyatakan bahwa mengarang, tidak hanya menyusun kalimat-kalimat singkat dengan satu objek atau predikat, akan tetapi harus menggabungkan beberapa kalimat singkat menjadi satu kalimat dan membetuk beberapa paragraf.

Penggunaan tanda baca dan penulisan penulisan huruf kapital perlu menjadi perhatian bagi peserta didik. Peserta didik sudah cukup dalam menggunakan dan menuliskan ejaan yang sesuai dalam tulisan, tetapi beberapa peserta didik masih belum memerhatikan penggunaan tanda baca dan penulisan penulisan huruf kapital di awal kalimat dalam menulis karangan deskripsi yang tidak tepat.

Bagian karangan yang ditulis belum sesuai dengan Pedoman Umum Ejaan Bahasa Indonesia
(PUEBI). Oleh karena itu, peran guru sangat dibutuhkan untuk lebih membimbing peserta didik dalam penggunaan dan penulisan huruf kapital dan penggunaan tanda baca, agar peserta didik terbiasa menulis karya tulis sesuai dengan aturan yang berlaku atau sesuai dengan Pedoman Umum Ejaan Bahasa Indonesia (PUEBI).

Berdasarkan hasil wawancara pada wali kelas IV dan beberapa peserta didik yang menjadi subjek, temuan mengenai kesulitan menulis karangan deskripsi di SDN Griya Bandung Indah adalah yang dihadapi peserta didik berkaitan dengan menulis karangan deskripsi yaitu berupa kesalahan dalam hal penggunaan huruf kapital. Kesalahan ini sudah terbiasa terjadi, peserta didik berulang kali melakukan kesalahan tanpa ada pembenaran dari pendidik. Selain itu, peserta didik meremehkan ketika diperingatkan bahwa hasil tulisannya belum benar. Mereka beranggapan bahwa tidak masalah tulisan salah, yang penting jawaban yang mereka kerjakan benar.

Dengan demikian, dapat disimpulkan bahwa kemampuan menulis karangan deskripsi peserta didik kelas IV SD Negeri Griya 
Bandung Indah termasuk ketegori masih rendah. Beberapa kriteria yang belum mampu dicapai peserta didik, terutama pada pengolahan kata dan penggunaan tanda baca. Peserta didik kurang mampu menggunakan kata baku atau sesuai Pedoman Umum Ejaan Bahasa Indonesia dalam tulisannya serta kurang memerhatikan tanda baca untuk memudahkan pembaca memahami hasil karya tulisnya. Hal itu terjadi karena kurangnya kontrol dari guru pada setiap tugas peserta didik dalam menulis.

\section{Hambatan Yang Dihadapi} Peserta Didik Kelas IV SD Negeri Griya Bandung Indah dalam menulis karangan deskripsi

Dari hasil dokumentasi yang telah dilakukan, secara keseluruhan peserta didik memiliki kendala dalam menulis karangan deskripsi. Berdasarkan hasil analisis peserta didik masih kurang siap menulis sebuah karangan, menentukan ide berdasarkan tema yang akan dideskripsikan serta peserta didik masih bingung dan perlu diberikan contoh terlebih dahulu untuk membuka pemikiran peserta didik. Peserta didik tidak menulis dalam bentuk kasar ide yang dimiliknya terlebih dahulu. Oleh karena itu, peserta didik terkadang lupa dengan ide yang dimiliki untuk dituangkan dalam bentuk kata/kalimat. Ide yang disusun peserta didik pun masih tergolong kurang teratur karena ide yang disusun menjadi kata/kalimat masih kurang berkaitan antara satu kata/kalimat dengan kata/kalimat selanjutnya. Sebagian besar peserta didik enggan memperbaiki ulang atau menambahkan ide-ide baru terhadap karyanya. Dengan kata lain, peserta didik miskin kata-kata.

Karangan yang disusun peserta didik rata-rata hanya sekitar 4-6 kalimat. Pemikiran peserta didik kurang berkembang hal tersebut terbukti dengan hasil dokumentasi yang menunjukkan pada aspek kesesuaian gagasan karangan yang hanya $54 \%$ dan peserta didik yang memenuhi kriteria hanya 36\%, $7 \%$ sedangkan yang tidak memenuhi kriteria 63,3\%. Oleh karena itu, peserta didik tidak mampu mengembangkan kalimat yang disusun. Selanjutnya peserta didik masih kurang memerhatikan bentuk tulisannya, misalnya jarak antar kata yang masih berantakan yang menyebabkan pembaca kurang memahami maksud kalimat yang 
Didaktik : Jurnal IImiah PGSD STKIP Subang, ISSN Cetak : 2477-5673 ISSN Online : 2614-722X Volume 07 Nomor 01, Juni 2021

disusun. Hal ini dapat dibuktikan dengan hasil dokumentasi yang menunjukan pada aspek kerapihan tulisan dan ketepatan diksi yang hanya $47,5 \%$ dan peserta didik yang memenuhi kriteria hanya $26,7 \%$ sedangkan yang tidak memenuhi kriteria $73,3 \%$.

Selanjutnya penggunaan tanda baca tidak diperhatikan, sehingga sebagian peserta didik tidak menggunakan tanda baca dalam penulisan karangan tersebut. Hal ini dibuktikan dengan hasil dokumentasi yang menunjukan pada aspek pedoman umum ejaan bahasa indonesia yang hanya $38,25 \%$ dan peserta didik yang memenuhi kriteria hanya $13 \%$ sedangkan yang tidak memenuhi kriteria $87 \%$. Hal ini sesuai dengan penelitian Sanita, Marta dan Nurhaswinda (2020, hlm. 241) yang menjelaskan bahwa peserta didik masih merasa kesulitan untuk menuangkan apa yang perlu ditulis, serta kebingungan memulai dari mana apa yang akan ditulisnya tidak memperhatikan ejaan, huruf kapital, dan keruntutan kalimat. Adapun hasil penelitian Purbania, Rohmadi, Setiawan (2020:70) menjelaskan bahwa kesulitan yang dihadapi peserta didik dalam menulis karangan deskripsi yaitu kesulitan untuk mengemukakan ide gagasan, mengembangkan kata menjadi kalimat, menentukan ejaan yang baik dan benar; dan konsentrasi dalam pembelajaran.

Berdasarkan hasil wawancara yang dilakukan dengan guru kelas IV SD Negeri Griya Bandung Indah, secara umum pada setiap proses mengajar pasti terdapat beberapa kendala yang dialami guru. Khususnya dalam mengajar menulis karangan deskripsi, terdapat beberapa kendala yang dialami guru. Meskipun menemukan kendala dalam mengajar, guru berusaha mencari dan memikirkan cara untuk mengatasi kendala yang dialaminya. Hal ini menjadi tantangan bagi guru untuk terus berlatih dan memperbaiki kualitas mengajar agar mampu mengatasi kendala tersebut. Dalam menulis karangan deskripsi, guru mengakui bahwa terdapat kendala yang biasanya dihadapi peserta didik. Mereka kesulitan menuangkan ide yang dimilikinya ke dalam bentuk kata dan menyusun menjadi kalimat.

Guru pun merasa kesulitan membuka pemikiran peserta didik untuk menuangkan ide yang sudah ada pada pikiran peserta didik 
menjadi bentuk kata/kalimat. Hal ini menyebabkan minimnya kata-kata yang disusun menjadi sebuah karangan. Dengan demikian, guru dituntut untuk dapat mengatasi rendahnya minta membaca yaitu memberikan wacana yang menarik sehingga peserta didik termotivasi untuk gemar membaca, dan peserta didik untuk membiasakan latihan dengan bersungguh dalam membuat karangan agar mampu menyusun kata-kata dan mengembangkan kalimat. Penelitian yang dilakukan Naki, dkk (2018:275) menyebutkan bahwa kendala yang dihadapi peserta didik dalam menulis karangan deskripsi yaitu peserta didik kurang menguasai kaidah ejaan yang baik, peserta didik kurang serius dalam mengerjakan tugas, dan adanya pengaruh ragam bahasa.

Berdasarkan hasil wawancara yang dilakukan dengan peserta didik terkait kendala yang dihadapi dalam menulis karangan deskripsi peserta didik hampir sama bahwa menulis karangan deskripsi masih dianggap susah oleh peserta didik, karena pada saat menulis, ide yang sudah ada dipikiran sulit untuk disalin menjadi kata/kalimat, perlu berfikir lama untuk dapat memperoleh ide yang menarik.
Jika ditugaskan menulis karangan deskripsi, peserta didik mampu menuliskannya namun masih merasa kesulitan.

Salah satu kesulitan menulis karangan deskripsi adalah peserta didik cepat lupa dengan ide yang masih tersimpan dipikiran untuk dituliskan menjadi kata/kalimat. Hal tersebut yang menyebabkan peserta didik malas untuk berlatih menulis karangan deskripsi karena dijelaskan bahwa membutuhkan pemikiran yang luas. Selain itu, dalam menulis karangan deskripsi yang diutamakan adalah menggali ide yang dimiliki menjadi kata/kalimat sehingga membentuk beberapa paragraf. Hal ini sejalan dengan pendapat Keraf (2010:84) yang menyatakan bahwa dalam deskripsi seorang penulis memindahkan kesan-kesannya, memindahkan hasil pengamatan, dan perasaannya kepada para pembaca.

Dari paparan diatas, maka dapat disimpulkan bahwa hambatan yang dihadapi yaitu permahaman peserta didik dalah kesulitan dalam pengembangan ide gagasan ke dalam tulisan, penulisan yang tepat sesui PUEBI dan minat belajarnya yang kurang. Selain itu, faktor dari guru pun sangat berpengaruh, yaitu guru tidak 
menggunakan model pembelajaran yang emnarik peserta didik untuk terbiasa dalam menulis, sehingga membuat peserta didik jarang untuk melakukan latihan mengarang, kebingungan ketika mengembangkan kata-kata dan paragraf yang ada di dalam karangan.

\section{Faktor Yang Memengaruhi} Peserta Didik Kelas IV SD Negeri Griya Bandung Indah dalam menulis karangan deskripsi

Berdasarkan hasil wawancara terhadap wali kelas IV terdapat beberapa faktor penyebab rendahnya hasil karangan yang ditulis peserta didik, antara lain ada yang sulit karena memang tingkat kecerdasannya kurang, ada yang karena konsentrasi belajar, sikap, dan perilaku. Bahkan Ketika pembelajaran berlangsung, peserta didik ini terlihat banyak bergerak, tidak bisa tenang mengikuti pelajaran walaupun hanya setengah jam. Ketika guru keluar sebentar saja dia sudah memanfaatkan waktunya dengan santai pamit ke kamar mandi dengan waktu yang lama. Jika dia merasa bosan di dalam kelas dan bosan mengerjakan tugas yang diberikan guru, dia lebih memilih untuk bermain sendiri. Dia tidak peduli pada tugas yang diberikan.
Dari hasil dokumentasi dan wawancara peneliti menyimpulkan bahwa faktor yang mempengaruhi kesulitan menulis karangan deskripsi adalah faktor sikap dan perilaku. Terdapat peserta didik ketika mengerjakan tes yang diberikan oleh guru dengan jawaban asal-asalan. Hal ini adalah bukti bahwa peserta didik ini memang kesulitan dalam hal menulis karangan. Ketika guru menerangkan materi tentang karangan deskripsi, peserta didik ini diam saja, terlihat gampang bosan dengan pelajaran. Ketika dia bosan dengan pelajaran, dia mengajak temannya untuk berbicara, sehingga ketika diberikan tugas siswa tidak mengerti. Dapat disimpulkan bahwa kesulitan menulis karangan yang dialami disebabkan oleh tingkat kecerdaan peserta didik kurang, maka akan sulit menerima ilmu yang diberikan. Faktor lain yang berasal dari dalam diri peserta didik yaitu kurangnya minat membaca, kecerdasan, dan motivasi yang dimiliki peserta didik sehingga peserta didik masih kesulitan untuk menemukan ide yang dijadikan bahan menulis karangan. Hal ini menjadi penyebab utama peserta didik memperoleh nilai rendah. Selain itu, didalam menulis karangan deskripsi pun harus memiliki 
Didaktik : Jurnal IImiah PGSD STKIP Subang, ISSN Cetak : 2477-5673 ISSN Online : 2614-722X Volume 07 Nomor 01, Juni 2021

pengetahuan yang luas agar mampu mendeskripsikan suatu objek dengan jelas dan dapat diterima oleh pembaca.

Berdasarkan paparan di atas, menujukan bahwa kesulitan menulis peserta didik salah satunya dapat dipengaruhi oleh pendidik (guru). Faktor tersebut memicu terjadinya kesulitan dalam belajar. Ketika guru menyampaikan materi tentang menulis karangan deskripsi, pendidik menyampaikan materi dengan metode ceramah. Kemudian pendidik memberikan tes pada peserta didik, tidak dijelaskan terlebih dahulu bagaimana cara dan maksud mengerjakannya, hasilnya mereka kurang memahami perintah soal yang diberikan dan akhirnya jawaban mereka banyak yang tidak sesuai dengan perintah soal.

Berdasarkan hasil penelitian yang diperoleh selain cara mengajar tetapi bahwa sarana dan prasana penunjang pembelajaran khususnya materi menulis karangan deskripsi masih kurang, dalam mengajar hanya menggunakan buku ajar yang disediakan pihak sekolah untuk menunjang proses pembelajaran. Rencana Pelaksanaan Pembelajaran (RPP) yang digunakan guru mengajar karangan deskripsi sebelumnya kurang sesuai dengan karakteristik siswa dikelas IV, karena guru menggunakan RPP yang disusun oleh Kelompok Kerja Guru (KKG). Setiap mengajar guru jarang membuat Rencana Pelaksanaan Pembelajaran (RPP) baru untuk materi yang akan diajarkan. Guru tidak menggunakan Rencana Pelaksanaan Pembelajaran (RPP) sebagai acuan dalam mengajar. Padahal, guru dituntut untuk dapat membimbing peserta didik dan memberikan motivasi agar terjadi proses interaksi yang baik sehingga senang dan nyaman dalam belajar. Oleh karena itu, guru harus mempunyai metode yang tepat untuk menyampaikan materi kepada peserta didik. Hal ini disebabkan karena, guru dapat memengaruhi hasil belajar peserta didik.

Faktor yang menyebabkan rendahnya hasil karangan yang ditulis oleh peserta didik antara lain dari faktor internal dan faktor eksternal. Faktor internal yang meliputi faktor yang berasal dari diri peserta didik yaitu kurangnya minat membaca yang dimiliki oleh peserta didik sehingga siswa masih kesulitan untuk menuangkan ide yang dijadikan bahan menulis karangan. Hal ini 
sesuai dengan pendapat Zaenudin (2015:10) yang menjelaskan bahwa faktor yang memengaruhi kemampuan menulis peserta didik adalah kurang lancar mengeluarkan ide-ide dengan menggunakan Bahasa Indonesia karen kurangnya membaca, kurang terbiasa menggunakan Bahasa Indonesia dalam berkomunikasi sehari-hari, kurangnya pemahaman siswa tentang tema cerita, kurangnya kemampuan dalam berpikir abstrak dan perkembangan kognisi siswa yang baru mencapai tahap operasional konkrit, sehingga dalam menulis karangan masih sangat membutuhkan alat untuk membantu mengeluarkan ide dan gagasannya dalam bentuk karangan. Oleh karena itu, untuk menulis karangan deskripsi harus memiliki pengetahuan yang luas agar dapat mendeskripsikan suatu objek dengan jelas dan dapat diterima oleh pembaca.

Faktor eksternal rendahnya kemampuan menulis karangan deskripsi meliputi faktor guru (strategi pembelajaran guru) dan sarana prasarana yang disediakan untuk menunjang proses pembelajaran. $\mathrm{Hal}$ ini sesuai dengan pendapat Abidin (2013:190) yang menjelaskan faktor yang memenagruhi kerampilan menulis salah satunya dari gurunya yaitu rendahnya peran guru dalam membina siswa agar terampil menulis, kurangnya sentuhan guru dalam hal memberikan berbagai strategi menulis yang tepat dan penggunaan pendekatan menulis yang kurang tepat. Adapun pendapat Abdurrahman (2012:28) yang menyatakan bahwa faktor guru dapat berupa strategi pembelajaran yang keliru seperti pengelolaan kegiatan belajar yang tidak membangkitkan motivasi belajar anak, metode yang kurang bervariasi sehingga pembelajaran menjadi membosankan, penggunaan media pembelajaran atau alat peraga yang kurang dan rendahnya peran guru dalam membina peserta didik agar terampil menulis dan berlatih mengemukakan gagasan masih belum optimal dikembangkan. Hal ini pun sesuai dengan hasil penelitian Naki, Nurhayati, Abidin (2018, hlm.275) yang menjelaskan bahwa guru masih menggunakan metode pembelajaran tradisional, terbatasnya guru untuk menyediakan media gambar yang sesuai dengan konsep pembelajaran dan guru belum mampu menggunakan media 
pembelajaran gambar berseri secara kontinu.

\section{E. Kesimpulan}

Berdasarkan hasil penelitian, analisis data, dan pembahasan yang telah dikemukakan pada bab sebelumnya, secara umum dapat disimpulkan bahwa:

1. Kemampuan menulis karangan deskripsi siswa kelas IV SDN Griya Bandung Indah secara keseluruhan masih perlu ditingkatkan. Rata-rata kemampuan menulis karangan deskripsi yaitu 54,6 dengan kualifikasi kurang. Adapun persentase masing-masing aspek yaitu sebagai berikut. (a) Persentase kesesuaian judul dengan tema karangan adalah $66 \%$ atau sama dengan 20 peserta didik termasuk katerogi sangat baik/ baik, sedangkan sisanya yaitu $34 \%$ atau sama dengan 10 peserta didik masih belum mampu menentukan judul sesuai dengan tema karangan,(b) persentase kerapihan tulisan dan ketepatan diksi adalah adalah $26,7 \%$ atau sama dengan 8 orang termasuk kategori sangat baik/baik, sedangkan sisanya $73,3 \%$ atau sama dengan 22 orang yang masih kurang rapi dalam penulisannya dan pilihan kata/diksi, (c) persentase struktur penulisan karangan adalah $56,7 \%$ atau sama dengan 17 orang termasuk kategori sangat baik / baik, sedangkan sisanya $43,3 \%$ atau sama dengan 13 orang yang masih kurang dalam struktur penulisan karangan, (d) persentase kesesuaian gagasan dengan karangan adalah $36,7 \%$ atau sama dengan 11 orang termasuk kategori sangat baik/baik, sedangkan sisanya $63,3 \%$ atau sama dengan 19 orang masih kurang dalam kesesuaian gagasan dengan tulisan karangan, (e) persentase penggunaan ejaan umum bahasa indonesia adalah $13 \%$ atau sama dengan 4 orang yang termasuk kategori sangat baik/baik, sedangkan sisanya adalah $87 \%$ atau sama dengan 26 orang termasuk kategori kurang dalam penulisan huruf kapital dan penggunaan tanda baca sesuai dengan pedoman umum ejaan bahasa indonesia.

2. Terdapat hambatan yang dihadapi peserta didik kelas IV dalam menulis karangan deskripsi yaitu (a) peserta didik merasa sulit dalam menuangkan ide yang dimilikinya menjadi bentuk kata/kalimat, (b) 
pemikiran peserta didik kurang berkembang, sehingga merasa sulit untuk merangkai kata menjadi beberapa kalimat, (c) peserta didik cepat lupa dengan ide yang masih tersimpan dipikiran untuk dituliskan menjadi kata/kalimat,

3. Terdapat beberapa faktor yang mempengaruhi kesulitan belajar menulis karangan deskripsi bahasa Indonesia di SDN Griya Bandung Indah adalah faktor kecerdasan, faktor minat belajar, faktor sikap dan perilaku terhadap pelajaran, faktor motivasi, dan faktor dari pendidik yang menggunakan media, metode, dan taktik pembelajaran yang belum tepat.

\section{DAFTAR PUSTAKA}

Abdurrahman, M. (2012). Anak berkesulitan belajar; Teori, diagnosis dan remediasinya. Jakarta: Depdikbud.

Abidin, Y. (2013). Pembelajaran Bahasa Berbasis Pendidikan Karakter. Bandung: Refika Aditama.

Azizah, I,N.(2016). Peningkatan Keterampilan Menulis Karangan Deskripsi Menggunakan Media Audio Visual Pada Siswa Kelas
IV SD. Jurnal Pendidikan Guru Sekolah Dasar. 2(24).

Dalman. (2012). Keterampilan Menulis. Jakarta: Raja Grafindo Persada.

Dalman. (2013). Keterampilan Menulis. Jakarta: Raja Grafindo Persada.

Dalman.(2015). Keterampilan menulis. Jakarta: Raja Grafindo Persada.

Dalman.(2016). Keterampilan menulis. Jakarta: Raja Grafindo Persada. Dalman. (2018). Keterampilan Menulis. Jakarta: Raja Grafindo Persada.

Fatkasari, Dyah. Heru, Subrata.(2017). Pengaruh Model Pembelajaran Kooperatif Tipe Think Talk Write Terhadap Keterampilan Menulis Deskripsi Siswa Kelas IV SDN Petung Asri 3 Kecamatan Pandaan Kabupaten Pasuruan. Jurnal Pendidikan Guru Sekolah Dasar. 5(03).

Keraf, Gorys. (2010). Diksi dan Gaya Bahasa. Jakarta: PT Gramedia Pustaka Utama.

Moleong, L. J.(2010). Metodologi Penelitian Kualitatif. Bandung: Remaja Rosda Karya. 
Didaktik : Jurnal IImiah PGSD STKIP Subang, ISSN Cetak : 2477-5673 ISSN Online : 2614-722X Volume 07 Nomor 01, Juni 2021

Naki, Nurhayati, Abidin. (2018). Analisis Kemampuan Menulis Karangan Deskripsi Dalam Bahasa Indonesia Melalui Media Gambar Seri Pada Siswa Kelas VII SMP N 18 Lau Kabupaten Maros. Jurnal IImu Budaya. 6 (2). Nurgiyantoro, B. (2010). Penilaian Pembelajaran Bahasa. Yogyakarta: Gajah Mada University Press.

Nurhuda, Asep.(2018). Pengaruh Model Pembelajaran Kooperatif Tipe Think Talk Write Dengan Menggunakan Media Gambar Terhadap Keterampilan Menulis Karangan Deskripsi Di Sekolah Dasar. Thesis Prodi Pendidikan Dasar, SPS UPI : Tidak Diterbikan.

Purbania, Basyaroh., Rohmadi, Muhammad., Setiawan Budhi., (2020). Kemampuan Menulis Teks Deskripsi Siswa Sekolah Menengah Kejuruan. BASASTRA Jurnal Bahasa, Sastra, dan Pengajarannya. (8 (1).

Sri Sanita ,Sri., Marta Rusdial., Nurhaswinda.2020. Peningkatan Kemampuan Menulis Karangan Deskripsi dengan Metode Pembelajaran Field Triep.
JOURNAL ON TEACHER EDUCATION, 2 (1).

Santoso, Anang, dkk. (2013). Materi dan Pembelajaran Bahasa Indonesia SD. Banten: Universitas Terbuka.

Suyuti, Yulian., Sugit Zulianto., \& Yunidar, Nur.(2016). Penerapan media gambar dalam upaya meningkatkan kemampuan menulis karangan deskripsi siswa kelas XB SMAN 2 DAMPELAS.e-Jurnal Bahasantodea, 4(2).

Tarigan, H. G. (2013). Menulis Sebagai Suatu Keterampilan Berbahasa. Bandung: Angkasa.

Zaenudin. (2015). Pembelajaran Mengarang Deskripsi di Sekolah Dasar. Yogyakarta: Tiara Wacana.

Zulela. (2013). Pembelajaran Bahasa Indonesia Apersiasi Sastra Di Sekolah Dasar. Bandung: Remaja Rosdakarya. 